\title{
Rebecca Rogers \\ From the Salon to the Schoolroom: Educating Bourgeois Girls in Nineteenth-Century France.
}

Pennsylvania: Pennsylvania State University Press, 2005. vii, 333 pp.

\author{
Patrick J. Harrigan \\ Distinguished Professor Emeritus of History, University of Waterloo
}

Like all of Rebecca Rogers' work, From the Salon to the Schoolroom: Educating Bourgeois Girls in Nineteenth-Century France is meticulously researched, clearly written, and incisive. It is a history of the many independent schools both lay and religious that developed in France before the State established its own girls' secondary schools with the Sée law of 1880. But Salon to Schoolroom is much more than an institutional history, for Rogers relates schooling to the formation of bourgeois women, to public and private spheres, and to the family and society as a whole. Living in France, Rogers has scoured letters, diaries, and school brochures, accessing records of private lay schools that remained undiscovered in departmental and private archives.

The French Revolution disrupted the network of religious and lay Parisian girls' schools that had been founded in the eighteenth century, as it brought temporary havoc to schooling, charitable institutions and trade in the 1790s. Their demise allowed new private initiatives and innovation by a wide variety of educators. Besides the religious orders, there was another group of lay boarding school mistresses, whom Rogers considers “emerging professional women." In mid-century, lay girls schools in Paris outnumbered religious ones by a factor of fifteen to one (320 to 22); in 1864, 79,521 girls attended these schools (168). Rogers credits schools with encouraging female adolescents to see themselves "as individuals with unique characteristics. As a result more and more girls...aspired to a life beyond the family" (254). "The education necessary to produce learned, serious, and domestic women opened doors outside the home as well” (258). In a revisionist mode, she finds schools emancipatory rather than confining.

Schooling in France was class-divided with secondary schools, which taught Latin and Greek, intended for the middle classes. In 1853, Paris dictated that all girls' 
schools were to be counted as elementary schools. This decree has led to confusion about the role and intention of many girls' schools. Admittedly, the boundaries were blurred in many cases and Rogers may be a bit too confident in her distinctions. Nevertheless, she demonstrates irrefutably that many schools attracted bourgeois families and taught a curriculum that was secondary in some cases, including Latin and Mathematics.

Rogers' evidence refutes a number of canards long-present in the historiography; that there were no secondary girls' schools in France before the Sée law; that nuns' schools were universally inferior; that the Church resisted girls' schooling; that lay school mistresses were unqualified; that girls were only trained for domesticity. The Church educated a majority of French girls until the anticlerical restrictions of the Ferry Laws, 1880-82; despite legal restrictions, it still educated more than forty percent at the end of the century. Rogers labels Msgr. Felix Dubanloup a feminist, for his defence of woman's right to a serious education with mental as well as religious instruction $(4,158)$. He is remembered in republican circles only for his opposition to Victor Duruy's plan for a secular-based girls' schooling for teenage girls. Two interpretations - local initiative led to more innovation than in State schools and that a "system" of girls schooling existed before State legislation - echo arguments made by Raymond Grew and myself about primary schooling in School, State and Society: The Growth of Elementary Schooling in Nineteenth Century France (Ann Arbor, Mi: University of Michigan Press, 1991). Unfortunately, girls' schooling became the focal point for "Political Battles for Women's Minds in the Second Half of the Nineteenth Century" (Chapter 7). Both Church and State became preoccupied with denying the other's place in schooling rather than advancing education for all.

In a unique final chapter, Rogers shows the influence of the French model of girl's education beyond French borders by exploring its interactions with other national and cultural traditions. We know of the spread of revolutionary ideals and the Napoleonic law codes to South America, Quebec, and French colonies, but no one, to my knowledge, has explored the export of educational ideals not only to colonies but also to Great Britain and the United States. An influential book about Catholic girls' education written by Janet Stuart, superior general of the Société du Sacré Coeur, appearing in the United States as Education: How Old the New? (1914) brought the French Catholic model of rigorous study across the Atlantic.

Originally a social historian, Rogers acknowledges her debt to the pioneering work of Francoise Mayeur. This book incorporates trends in gender history and cultural history as well. Rogers weaves schooling into considerations of "identity" by depicting the rich variety of ideas to which young women were exposed. Schooling enriched those who attended, and rather than confining them to a domestic role, enabled them to move between the public and private spheres and preserve active roles within the family. 